\title{
Sosialisasi Model House Of Quality Produk Eceng Gondok Dalam Perbaikan Mutu Pada Umkm Rumah Anyamandiri di Kota Makassar
}

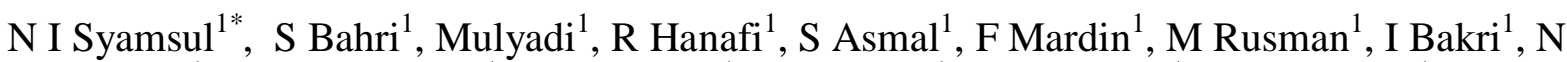 \\ Syamsul $^{1}$, D R Mudiastuti ${ }^{1}$, S Mangenre ${ }^{1}$, I Setiawan ${ }^{1}$, S Parenreng $^{1}$, A B R Indah ${ }^{1}$, M A \\ Darmawan $^{1}$, K Amar ${ }^{1}$. \\ Teknik Industri, Fakultas Teknik Universitas Hasanuddin ${ }^{1}$ \\ nadzirah.ikasari@yahoo.com*
}

\begin{abstract}
Abstrak
Di tengah Pandemi yang terjadi saat ini sekitar $72 \%$ para pelaku usaha UMKM mengalami penurunan pendapatan. Hal tersebut bukanlah membuat para pelaku UMKM harus berdiam diri, namun harus mengambil langkah dan strategi untuk maju kedepan. Usaha Mikro, Kecil dan Menengah (UMKM) memiliki peran penting dalam perekonomian masyarakat Indonesia. Beberapa hal peran UKM dalam kehidupan masyarakat kecil yakni, sarana mengentaskan masyarakat dari jurang kemiskinan, sarana untuk meratakan tingkat perekonomian rakyat kecil, dan memberikan pemasukan devisa Negara. Dengan mendorong UMKM naik kelas dapat mengurangi tingkat kemiskinan sekitar $20 \%$ atau setara dengan mengeluarkan 5 juta orang dari kemiskinan. Selain itu dapat mengurangi tingkat ketimpangan sekitar 4\%. Oleh karenanya dukungan dari berbagai pihak untuk meningkatkan kualitas ditengah pandemic saat ini sangatlah dibutuhkan. Salah satu UMKM yang memiliki produk unggulan saat ini adalah sandal eceng gondok dan tas Anyaman yakni UMKM Anayamandiri binaan Dekranasda provinsi. Perbaikan dan $\mathrm{p}$ eningkatan mutu produk merupakan hal dasar yang harus dimiliki oleh para pelaku UMKM agar dapat menjaga dan meningkatkan jumlah pelanggannya. Oleh karena itu, Suatu Metode Quality Fungtion Development merupakan salah satu pendekatan kepada pelanggan dengan membuat Voice of customer serta mampu mendesain matriks house of quality terhadap setiap produk-produk UMKM.
\end{abstract}

Kata Kunci: UMKM; Mutu; Perekonomian; Quality Fungtion Development; House Of Quality.

\begin{abstract}
In the midst of the current pandemic, around 72\% of MSME business actors have experienced a decline in income. This does not make MSME players have to be silent, but they must take steps and strategies to move forward. Micro, Small and Medium Enterprises (MSMEs) have an important role in the economy of Indonesian society. Several aspects of the role of SMEs in the life of small communities, namely, facilities to alleviate the community from the abyss of poverty, means of leveling the economic level of the small people, and providing foreign exchange income. By encouraging MSMEs to upgrade to grades, it can reduce the poverty rate by around $20 \%$ or the equivalent of removing 5 million people from poverty. In addition, it can reduce the inequality rate by about 4\%. Therefore, support from various parties to improve quality in the midst of the current pandemic is needed. One of the MSMEs that currently has superior products is water hyacinth sandals and woven bags, namely the Anayamandiri UMKM assisted by the provincial Dekranasda. Improvement and improvement of product quality are basic things that must be owned by MSME actors in order to maintain and increase the number of customers. Therefore, a Quality Function Development Method is an approach to customers by creating a Voice of customer and being able to design a house of quality matrix for each UMKM product.
\end{abstract}

Keywords: MSMEs; Quality; Economy; Quality Fungtion Development; House Of Quality.

\section{Pendahuluan}

Di tengah terjadinya pandemik Cov19 pada akhir tahun 2019 membuat para pengusaha mulai mengalami penurunan pada sector ekonomi. Hal ini terjadi dikarenakan adanya pembatasan sosial Berskala besar (PSBB), lockdown beberapa Negara, kemudian banyaknya para pegawai 
ataupun buruh mengalami pemberhentian kerja. Akibat salah satu kebijakan yang diambil pemerintah untuk mengurangi terjadinya penyebaran virus Cov19, yakni dengan diterapkannya PSBB, maka banyaknya kegiatan logistic terhenti. Namun justru ini bisa menjadi peluang bagi para pelaku UMKN untuk meningkatkan kesejahteraannya dengan membuat produk-produk kreatif dan berinovasi yang dibutuhkan oleh masyarakat setempat.

Usaha mikro, Kecil dan menengah (UMKM) memiliki peran penting dalam perekonomian masyarakat Indonesia. Beberapa hal peran UKM dalam kehidupan masyarakat kecil yakni, sarana mengentaskan masayarakat dari jurang kemiskinan, sarana untuk meratakan tingkat perekonomian rakyat kecil, dan memberikan pemasukan devisa Negara. Berdasarkan sumber Sindonews (Januari, 2020) dengan mendorong UMKM naik kelas dapat mengurangi tingkat kemiskinan sekitar 20\% atau setara dengan mengeluarkan 5 juta orang dari kemiskinan. Selain itu dapat mengurangi tingkat ketimpangan sekitar 4\%,

Saat ini pemerintah sudah mulai membantu pelaku UKM dan UMKM untuk mempercepat gerak mereka dalam mengembangkan usaha. Ada berbagai cara yang telah dilakukan mulai dari regulasi, perpajakan, mempermudah perizinan, jangkauan akses pasar yang luas serta pendanaan dengan bunga ringan. Salah satu kegiatan real yang telah dilakukan pemerintah adalah pameran produk-produk UKM ataupun UMKM. Khususnya di Sulawesi Selatan, UMKM dan UKM dibina langsung oleh Dekranasda Provinsi yang mana beberapa pembenahan telah dilakukan, yakni pelatihan peningkatan mutu, Kerjasama dengan Gojek-Grab, bantuan dana dari BI (bank Indonesia), serta mewajibkan beberapa hotel untuk menggunakan dan memamerkan produkproduk unggulan Sulawesi selatan dari hasil kerajinan produk UMKM.

Salah satu UMKM yang memiliki produk unggulan saat ini adalah sandal eceng gondok dan tas Anyaman yakni UMKM Anayamandiri binaan Dekranasda provinsi. UMKM ini telah bekerjasama dengan beberapa hotel di Makassar sejak 2019 dengan menyiapkankan sandalsandalnya yang bermaterial eceng gondok sehingga saat ini di beberapa hotel yang melakukan kerjasama mengganti sandalnya dari yang berbahan spon ke bahan eceng gondok serta memberikan ruang display produk-produk tas UMKM. Seperti yang kita ketahui bahwa tumbuhan eceng gondok memiliki manfaat bagi kesehatan.

Semakin banyaknya pesanan tentunya UMKM ini harus berbenah terus menerus dan mempertahankan mutu produknya guna menjaga relasi dengan konsumen. Selain itu UMKM ini harus mampu bersaing dengan UMKM-UMKM yang bermunculan. Tumbuhan eceng gondok sangat mudah didapatkan khususnya di Makassar dan Sulawesi selatan, sehingga membuat para pelaku usaha sangat dengan mudah untuk membuat produk tersebut baik dengan desain sendiri atau dengan mencontoh produk-produk yang ada. Adapun masalah- masalah yang tengah di hadapi UKM pada dasarnya adalah :

1. Para Pekerja terdiri dari warga/ tetangga yang memiliki taraf pendidikan yang rendah.

2. Para pekerja kurang kompetitif dalam meningkatkan inovasi.

3. Pemilik dan Para pekerja di UMKM membutuhkan wawasan tambahan terkait peningkatan mutu produk.

4. Belum memahami keinginan real para konsumen.

5. Adanya pesaing-pesaing yang bermunculan.

6. Banyaknya sumber daya Alam (eceng Gondonk) yang tumbuh liar, seperti pada gambar di bawah 


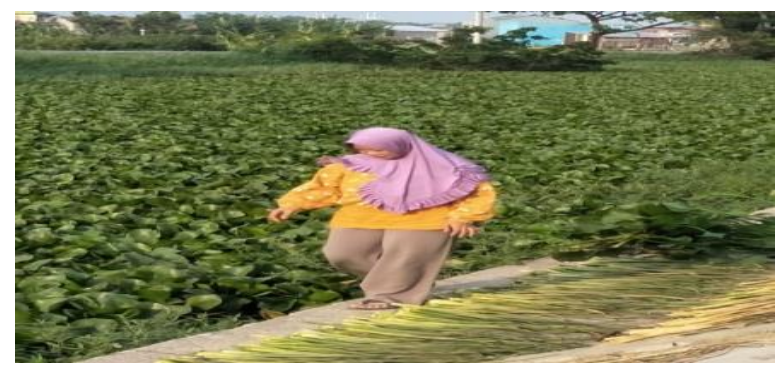

Gambar 1. Tumbuhan Eceng Gondok

Oleh karena itu para pelaku usaha harus memahami bagaimana suatu produk dituntut untuk memiliki Mutu dan membaca serta memahami keinginan dari para konsumen agar membuatnya unggul atau kompeten.

\section{Latar Belakang Teori}

Dalam meningkatkan persaingan saat ini harus memiliki strategi yang tepat, menurut Porter (1990) dalam obadi (2017) perusahaan memiliki aktivitas primer dan aktivitas sekunder yang harus dijalankan secara optimal untuk meningkatkan keunggulan kompetitif. Di persaingan yang cukup ketat perusahaan atau industri dituntut untuk memiliki kelebihan dibandingkan perusahaan atau industri lain, oleh sebab itu setiap perusahaan memiliki strategi dalam menghadapi persaingan (Varandarajan, et al, 1990). Khusus untuk produk - produk UMKM strategi yang mereka perlukan adalah bagaimana menciptakan prduk-produk yang kreatif, inovasi dan berMutu. Prinsip Mutu Tjiptono dan Chandra (2011) adalah sejumlah asumsi yang dinilai dan di yakini memiliki kekuatan untuk mewujudkan mutu.

\subsection{Quality Fungtion Developmennt}

Adanya asumsi-asumsi yang begitu banyak sehingga membutuhkan suatu metode untuk menafsirkannya. Quality function deployment atau yang biasa disebut (QFD) adalah metode untuk mengembangkan Mutu desain yang bertujuan untuk memuaskan konsumen dan kemudian menerjemahkan permintaan konsumen menjadi target desain dan poin utama Mutu jaminan untuk digunakan di seluruh tahap produksi (Kowalska, et all., 2015). Untuk mengetahui hal apa saja yang dibutuhkan dan diinginkan oleh pelanggan, perusahaan melakukan kegiatan me-list hal apa saja yang diinginkan pelanggan atau biasa disebut dengan voice of customers (VOC) dengan menggunakan tools atau pendekatan peningkatan Mutu. Salah satunya yaitu menggunakan Quality Function Deployment (QFD) untuk mengetahui apa saja yang diinginkan oleh pelanggan terhadap produknya. Penelitian ini menggunakan metode (QFD) hingga pada fase Design Deployment. QFD menurut Ficalora dan Cohen (2010) merupakan metode untuk produk terstruktur atau perencanaan pelayanan dan pengembangan yang memungkinkan suatu tim pengembangan untuk menentukan dengan jelas apa yang pelanggan inginkan dan butuhkan, dan kemudian menilai atau mengevaluasi setiap produk yang diusulkan atau kemampuan layanan sistematis dalam hal dampaknya karena memenuhi kebutuhan pelanggan tersebut. QFD fase 1 atau biasa disebut dengan rumah Mutu atau HoQ (House of Quality)

\subsection{House of Quality}

House of Quality (HOQ) merupakan suatu alat yang digunakan untuk mengetahui hal apa saja yang dibutuhkan dan inginkan tentang produk dari perusahaan sehingga didapatkan atribut untuk 
meningkatkan Mutu produk. Kegiatan ini akan disosialisasikan kepada pemilik usaha dan para pekerjanya.

Tahap penyusunan house of quality dibagi menjadi 6 langkah menurut Cohen (1995), sebagai berikut:

a) matriks kebutuhan pelanggan, meliputi: memutuskan siapa pelanggan, mengumpulkan data kualitatif berupa keinginan dan kebutuhan kosumen, menyusun keinginan dan kebutuhan yang sudah dikumpulkan, dan pembuatan diagram afinitas,

b) matriks perencanaan, meliputi: ukuran kebutuhan pelanggan, dan penetapan tujuan performansi kepuasan,

c) respon teknis, meliputi: transformasi dari kebutuhan konsumen yang bersifat non-teknis menjadi data yang bersifat teknis,

d) menentukan hubungan respon teknis dengan kebutuhan konsumen, meliputi: penentuan seberapa kuat respon teknis, hubungan sedang respon teknis, dan hubungan lemah respon teknis dengan kebutuhan pelanggan,

e) korelasi teknis, meliputi: pemetaan hubungan dan kepentingan antara karakteristik Mutu pengganti atau respon teknis, sehingga dilihat pengaruh dari respon teknis terhadap respon teknis lainnya, dan

f) benchmarking dan penetapan target, meliputi: menentukan respon teknis yang ingin dipilih dan dibandingkan dengan produk pesaing.

\section{Metode Untuk Menangani Permasalahan}

Dari berbagai masalah yang tengah dihadapi oleh para pelaku UMKM, maka selaku pengembang tri dharma perguruan tinggi dalam melaksanakan kegiatan pengadian kepada masayarakat, maka ada beberapa solusi untuk meningkatkan Mutu produknya seperti:

1. Memberikan pehamaman pentingnya memilih suatu strategi usaha dalam pencapaian tujuan

2. Memberikan penjelasan terkait QFD dalm peningkatan mutu produk pada UMKM

3. Memberikan Contoh Voice of Customer (VOC) agar mampu dengan mudah memahami keinginan para pelanggan

4. Memberikan sosialisasi terkait penjelasan sederhana dalam memahami penggunaan House of Quality

5. Memberikan contoh Pembuatan Matrix HOQ secara sederhana agar mampu melihat posisi UMKM dan memperhatikan apa saja yang perlu diperbaiki dan dikembangkan oleh UMKM

Adapun mekanisme dari kegiatan sosialisasi ini adalah :

1. Dalam memilih strategi untuk pencapaian usaha, maka akan diberikan pemahaman awal berupa, gembaran model usaha, diskusi dan Tanya jawab seperti brainstorming dengan pihak UMKM.

2. Penjelasan mengenai QFD secar sederhana yang mampu dipahami oleh para pekerja UMKM.

3. Menjelaskan contoh VOC dan cara menggunakannya kepada para pelanggan

4. Penjelasan mengenai penggunaan HOQ serta cara menggunakannya.

5. Pelaku kegiatan dalam hal ini pemilik UMKM, pegawai UMKM Anyamandiri, dan anggota Dekranasda Provinsi.

6. Evaluasi pelaksanaan program salah satunya dengan melihat desain produk terbaru serta metode produksi yang efektif selama kurang lebih 2 bulan 
Kegiatan sosialisasi Model HOQ pada UMKM Anyamandiri diharapkan kepada pemilik UMKM telah memutuskan strategi apa yang akan mereka terapkan serta para pegawai mampu memahmi pentingnya menjaga dan meningkatkan Mutu, serta seluruh peserta mampu memahami apa yang diinginkan para pelanggan.

Saat ini begitu banyak kegiatan pelatihan bisnis yang bermacam-macam, ada yang khusus untuk teknis produksi adapun khusus untuk keterampilan manejerial. Namun hanya saja banyak para pelaku UMKN tidak memanfaatkan peluang tersebut tentunya hal ini diakibatkan dari sisi biaya yang mahal. Padahal denganpelatihan tersebut tentunya banyak informasi bagi para UMKM untuk mengibarkan sayap usahanya. Oleh karena melihat kondisi tersebut Departemen Teknik Industri Fakultas Teknik membuat kegiatan pengabdian masyarakat pada UMKM Anyamandiri terkait bagaimana meningkatkan Mutu produk dengan menggunakan model HOQ pada Rabu, 8 Juli 2020 bertempat di Ruang Displai UMKM Anyamandiri jl. Poros Telkomas, kelurahan Berua Makassar. Kegiatan sosialisasi ini tetap menjalankan protocol kesehatan dengan menjaga jarak dan menggunakan masker seperti pada gambar 2 di bawah.
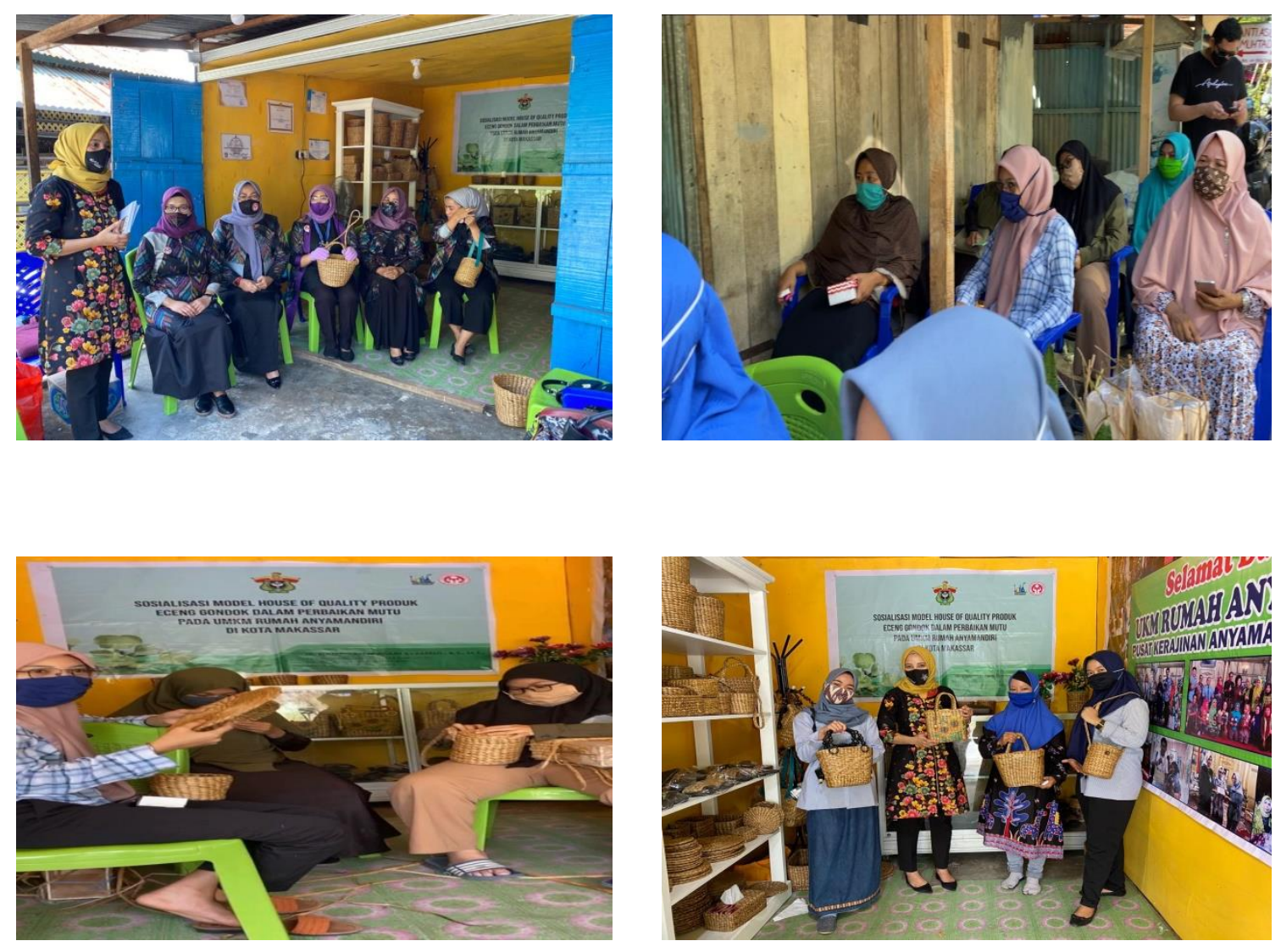


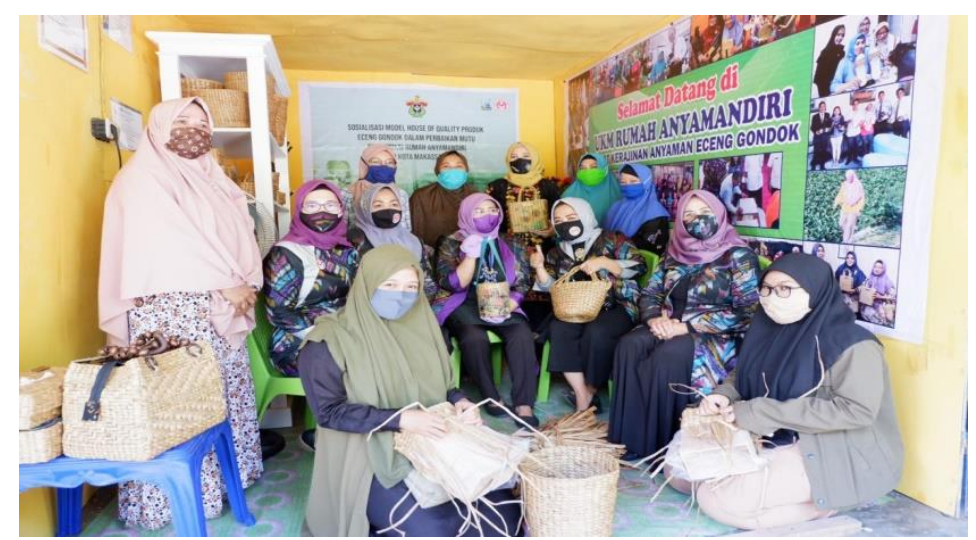

Gambar 2. Kegiatan sosialisasi

\section{Hasil dan Diskusi}

Kegiatan sosialisasi ini diikuti oleh pemilik UMKM, Pegawai UMKM serta anggota dekranasda Provinsi Serta ketua PKK Kec. Biringkanayya. Dari keseluruhan peserta telah memahami pentingnya peningkatan Mutu produk. Antusiasme dari para peserta telihat ketika banyaknya pertanyaan dan meminta untuk terus mengadakan kegiatan berkelanjutan. Pihak Dekranasda provinsi sul-sel sangat memberikan dukungan kepada para UMKM dan sengat berterimah kasih atas kegiatan sosialisasi yang telah dilaksanakan oleh FakultasTeknik UNHAS. Pemilik UMKN Anyamandiri juga paham bahwa kebutuhan untuk meningkatkan Mutu bukan hanya pada hasil produknya namun pada prosesnya. Oleh karenanya mereka juga sangat berharap kegiatan sosialisasi dengan tema yang lain untuk dilakukan terlebih dengan kondisi pandemic ini mereka harus giat melakukan promosi di sosial media. Karena untuk saat ini tidak ada lagi kegiatan pameran secara luring atau offline lagi. Sementara pegawai UMKM kurang paham mengenai tentang Media Promosi dan Mutu pelayanan.

\section{Kesimpulan}

Kegiatan Sosialisasi Model HOQ kepada para pelaku UMKM merupakan sesuatu yang sangat bermanfaat. Tentunya pengetahuan perbaikan dan peningkatan mutu pada prouk-produk UMKN menjadikan produk-produk mereka lebih andal dan dapat diterima dimasyarakat serta menjadikan sektor peningkatan eknomi masyarakat kecil. Kerjasama berbagai pihak sangat dibutuhkan dalam mewujudkan masyarakat terkhusus bagi pelaku UMKM sadar kualitas dan memiliki motivasi bekerja keras serta adapatif dalam perkembangan teknologi.

\section{Ucapan Terima Kasih}

UcapanTerima Kasih kepada semua pihak sehingga kegiatan pengabdian masyarakat Labo Based Educatian (LBE) dapat terlaksana dengan baik, terutama kepada : Fakultas Teknik atas penyelenggaraan kegiatan pengabdian masyarakat, Pemilik UMKM Anyamandiri ibu Elsa, Ketua Harian Dekranasda Provisi Sul-Sel A. Oci Alepuddin beserta Anggota, Ketua PKK Kec. Biringkanayya atas kerjasama yang baik selama berlangsungnya kegiatan ini, Mahasiswa yang telah membantu terselenggaranya kegiatan pengabdian, dan kepada seluruh peserta Sosialisasi model house of quality produk eceng gondok dalam perbaikan mutu pada umkm rumah anyaman diri. 


\section{Daftar Pustaka}

https://ekbis.sindonews.com/berita/1491550/34/mendorong-pertumbuhan-ekonomi-denganmemperkuat-umkm

https://economy.okezone.com/read/2020/09/15/455/2278068/84-pelaku-usaha-kecil-alamikerugian-selama-pandemi-covid-19

Obadi, S.M (2017). Competitive Advantage of Yemeni Export in the US Market. Open Access Library Journal, 4, 1-9. doi: 10.4236/oalib.1103852.

Varadarajan, et.all (1990). Strategic types, distinctive marketing competencies and organizational performance: A multiple measures-based study. https://doi.org/10.1002/smj.4250110504. Strategic Management Journal.

Cohen, Lou. (1995). Quality Function Deployment, How to Make QFD Work of You. New York: Addition Wesley Publising Company.

Bakar, Y., et.all (2012). Peningkatan kualitas produk dengan Quality Fun ction Deployment (QFD) di industri sepatu di kota padang. Jurnal teknik industri. Univer sitas Bung Hatta.

Kowalska, M. (2018).Implementation of QFD method in quality analysis of confectionery products. Springer link. Journal of Intelligent Manufacturing volume 29, pages439-447

Ficalora, J P., Cohen, Louis (2010). Quality function deployment and Six Sigma : a QFD handbook. Upper Saddle River, NJ : Prentice Hall

Cohen, Lou. (1995). Quality Function Deployment, How to Make QFD Work of You. New York: Addition Wesley Publising Company.

Tjiptono, F and Chandra,G. (2011). Service, Quality and Satisfaction, (ed3). Yogyakarta. Andi. 